\title{
Lea Laitinen
}

\section{Kirjallisuudentutkijat ja suomen kielen tulevaisuus?}

Tutkija(yhteisö)n ainoa laadun tae eivät voi olla julkaisut englanninkielisessä huippusarjassa. Yliopistojen tulisi virantäytöissä samoin kuin tutkimuksen arviointia varten laadittavissa julkaisuluokituksissa kehittää tapoja arvottaa myös kansallisilla kielillä laadittuja monografioita sekä kansallisesti relevantteja soveltavaan tutkimukseen keskittyviä julkaisuja ja julkaisusarjoja.

Näin kirjoitetaan toukokuussa ilmestyneessä julkaisussa Suomen kielen tulevaisuus, jossa kielentutkijat esittävät toimenpide-ehdotuksiaan suomen kielen julkisen käytön turvaamiseksi, kun englanti on alkanut monilla yhteiskunnallisesti tärkeillä toiminta-alueilla yleistyä nopeasti koko maailman yhteiseksi käyttökieleksi. ${ }^{1}$ Yksi raportin keskeisistä luvuista käsittelee tieteen kieltä. Siinä kartoitetaan yliopiston opetusta, tutkimuslaitoksia, tieteellisiä yhdistyksiä, julkaisuja ja terminologiaa ja pohditaan niiden tulevaisuutta kielipolitiikan näkökulmasta. Monien alojen tutkijoille tärkeitä ovat myös kieliteknologiaa ja koulua koskevat luvut.

Syksyllä kielipoliittinen tutkijakeskustelu onkin käynnistynyt; tieteen kielestä on puhuttu esimerkiksi Suomalaisen Tiedeakatemian, Tieteellisten seurain valtuuskunnan ja tietokirjailijoiden tilaisuuksissa. Samalla on käynyt selväksi, ettei kielellinen tietoisuus kasva tutkijayhteisössä ilman keskustelua, väittelyä ja tahallista provosointiakin. Se, että kielellä on ihmistieteissä olennaisempi osuus sekä tutkimuksen välineenä että tulosten esittämisessä kuin teknisten ja luonnontieteiden aloilla, luo helposti keskusteluissa pohjaa väärinymmärryksille, mutta ääneen sanottuna stereotypiatkin auttavat tiedeyhteisön itseymmärrystä enemmän kuin pelkkä hiljaisuus.

Kirjallisuudentutkijat ovat sidoksissa kieleen myös sillä tavalla, että heidän tutkimuskohteensa on kielellisen toiminnan tulosta. Kotimaisen kirjallisuuden tutkijat ovat lisäksi erityissuhteessa kansallisiin kieliin ja varsinkin suomen kielen kirjallistumisen kansalliseen historiaan. Ovatko kirjallisuudentutkijat siis kielellisesti erityisen tietoisia? Hehän tutkivat kielellistä merkityksenantoa. Mikä on silloin tutkijan oman äidinkielen merkitys? Milloin ja miten kielelliset valinnat ovat kirjallisuudentutkijoiden työssä ja työyhteisössä relevantteja?

\section{Taustaa}

Äidinkielen aseman ja yhteisöllisten tai yksilöllisten kielivalintojen pohtiminen ei ole pelkästään suomalainen ilmiö. Samoja asioita ratkotaan parhaillaan ympäri maailmaa. 
Vuonna 2002 Pohjoismaiden neuvoston vuosikertomuksessa kirjoitettiin:

Jos kehitys jatkuu samanlaisena, englanti saattaa vallata kaikkein keskeisimmät yhteiskuntaelämän alueet ja suomi, ruotsi, norja ja tanska typistyvät yksityiselämän ja kotien kieliksi. Englannista saattaa siis tulla yleiskieli, kun taas

Pohjoismaiden muut kielet muuttuisivat arkikieliksi. ${ }^{2}$

2000-luvun alussa kaikissa Pohjoismaissa onkin (Suomea lukuun ottamatta) kartoitettu maan kielitilanne ja laadittu kielipoliittiset ohjelmat valtioiden pääkielten ja monien vähemmistökieltenkin käytön tueksi. Ensimmäisenä teetti Ruotsin valtio vuonna 2002 laajan komiteamietinnön Mål $i$ mun; yksi sen tulos on viime heinäkuussa voimaan astunut Ruotsin kielilaki. Pohjoismaat julkaisivat vuonna 2005 kielipoliittisen julistuksen, ${ }^{3}$ johon ne kirjasivat yhteiset kieliperiaatteensa ja ilmoittautuivat samalla maailman kieliperinnön suojelussa kaikkien muiden maiden esikuvaksi. Tuohon julistukseen Suomikin virallisesti sitoutui.

Valtion kielipoliittista ohjelmaa meillä ei ole sen sijaan vielä tehty. ${ }^{4}$ Koska vuonna 2004 päivitetty 90 -vuotias kielilakimme ei voi ratkaista globaalistuvan kieliyhteisön kaikkia tarpeita, aukkoa täytettiin ensi hätään vapaamuotoisen työryhmän laatimalla raportilla Suomen kielen tulevaisuus. Opetusministeriö myönsi sitä varten Kotimaisten kielten tutkimuskeskukselle pienen määrärahan, mutta pääasiassa se syntyi Kotuksen ja Helsingin yliopiston tutkijoiden talkootyönä. Ohjelma korostaa, että kielipolitiikka on väistämättä osa kaikkea politiikkaa. Valtio harjoittaa kielipolitiikkaa silloinkin, kun se ilmenee pelkästään lausumattomina käytänteinä. Viisaampaa olisi määritellä eksplisiittisesti yhteiset kielelliset periaatteet ja sopia julkisesti myös niiden toteuttamisesta konkreettisella tasolla.

Esittämämme suosituksen mukaan Suomen valtiovallan olisi annettava eri aloja edustavan asiantuntijaryhmän tehtäväksi laatia kielipoliittinen kokonaisohjelma, joka koskee maan kielioloja ja kaikkia täällä käytettäviä kieliä. Suomen kielen tulevaisuus on yksi tuon ohjelman pohjatöistä; kotimaisista vähemmistökielistä on tekeillä omat ohjelmansa. ${ }^{5}$ Mutta tietysti myös suomalaisen tiedeyhteisön kannattaa arvioida implisiittisten kielikäytänteidensä perusteet itse eikä jättää niiden muotoilemista pelkästään poliitikoille.

\section{Ehdotuksia}

Ohjelman viimeiseen lukuun on koottu kaksikymmentäviisi tärkeintä toimenpideehdotusta ja merkitty myös näkyville, mitä tahoja ne erityisesti velvoittavat. Esittelen niistä lähinnä tutkimusta koskevia. Avaimen lukijoita saattaa lisäksi kiinnostaa myös koulujen kielivalintoja käsittelevä neljäs luku, jossa otetaan kantaa mm. äidinkielen ja kirjallisuuden opetukseen: sen tuloksethan ovat viidessätoista vuodessa romahtaneet. Neljännessä luvussa suositellaankin alakoulun luokanopettajille enemmän äidinkielen 
ja kirjallisuuden oppiaineen koulutusta, 5. ja 6. luokkien äidinkielenopetuksen siirtämistä aineenopettajille sekä lukion kurssien määrän palauttamista vuoden 1995 tasolle. Oppiaineen nimeksi esitetään muotoa suomen kieli ja kirjallisuus. Kuntien kieliohjelmat on suositusten mukaan rakennettava osaksi valtakunnallista kielipolitiikkaa ja sisällytettävä niihin konkreettiset esitykset siitä, mihin opetettaviin kieliin kunta sitoutuu.

Myös tutkimusta koskevassa viidennessä luvussa on lista suosituksia. Esitän ne tässä sellaisinaan. Ehdotusten perustelut ja niiden pohjana käytetty tietoaineisto esitetään samassa luvussa, joka alansa tulevaisuudesta kiinnostuneen tutkijan kannattaisi ilman muuta lukea.

- Suomen Akatemia tarvitsee kielipoliittisen ohjelman, jossa mm. määriteltäisiin Akatemian rahoitusta nauttivien tutkijoiden velvollisuus julkaista sekä kansainvälisesti että kotimaassa.

- Yliopistoille on laadittava kielipoliittinen ohjelma, jossa suomenkielinen opetus taataan. Ohjelman yhtenä osana olisi kansainvälisen toiminnan strategia. Ohjelman toteutumista valvomaan nimitetään kielipoliittinen toimikunta.

- Tiedekunnat ja kielikeskus määrittelevät yhdessä yhtenäiset perusteet kypsyyskokeiden arvioimiseen.

- Vakinaiseen virkaan nimitetyille ulkomaisille professoreille on yliopiston järjestettävä suomen (tai ruotsin) kielen opetusta niin, että professori voi seurata oppiaineensa ja yleisen hallinnoinnin tapahtumia. Vakinaisen viran haltijan on sitouduttava hankkimaan kohtuullisessa ajassa suomen (tai ruotsin) kielen taito.

- Gradun ja diplomityön kirjoittamisessa opetellaan tieteellistä kirjoittamista, jonka tulee pääsääntöisesti tapahtua suomeksi (tai ruotsiksi). Jos työ on kirjoitettu englanniksi, siinä on oltava suomenkielinen tiivistelmä.

- Niillä aloilla, joilla väitöskirjat laaditaan englanniksi, opiskelijan on esiteltävä tuloksiaan myös suomeksi.

- Opiskelijoiden ja tutkijoiden kielitaitoon on kuuluttava myös tieteellinen esittäminen ja kirjoittaminen äidinkielellä. Tutkijaksi koulutettaville ja tutkimushenkilöstölle järjestetään aloittain sekä suomenkielisen että englanninkielisen tieteellisen viestinnän opetusta.

- Vieraskielisen opetuksen ei tule rajoittua vain termistön opiskeluun, vaan sen on huomioitava myös toisesta kulttuurista lähtöisin oleva tieteellinen retoriikka ja tekstin rakentamisen tavat.

Näihin ehdotuksiin odotetaan palautetta myös kirjallisuudentutkijoilta. ${ }^{6}$ Alakohtainen itsearviointi ja tieteidenvälinen keskustelu on sitäkin tärkeämpää. Mitä esimerkiksi kotimaisen kirjallisuuden tutkimus ns. kansallisena tieteenä nykyisin voi merkitä? 
Suomenkielisyyttäkö? Osaavatko englanninkielisille markkinoille tähtäävät kirjallisuudentutkijat tehdä teoreettisesti ajantasaista tutkimusta suomeksi? Miten Avaimen kaltaiset kotimaiset julkaisut selviävät - ja mihin niitä tarvitaan?

\section{Kielet rinnakkain}

Useilla tekniikan ja luonnontieteen aloilla tutkimus on jo aika yksikielistä. Tieteenalan käsitteet, terminologia sekä tutkimuksen ja sen tulosten ilmaiseminen formaalisten esitystapojen lisäksi luonnollisella kielellä tehdään englanniksi; suomeksi annetaan perusopetusta ja julkaistaan populaaristuksia maallikoille. Vaarana on se, että syntyy muun väestön elämästä kielellisesti etääntyvä eliitti, ja demokratia supistuu. Kuva on silti karkea ja vastaa todellisuutta vain osittain. Suurin osa näidenkin alojen suomalaisista tutkijoista toimii edelleen Suomessa ja keskustelee suomalaisten kollegojensa kanssa päivittäin suomeksi, myös tutkimuksesta.

Ihmistieteissä tilanne on mutkikkaampi, koska ne ovat monin eri tavoin riippuvaisia kielestä. Tulosten taso saattaa jopa laskea siitä syystä, että tekijältä puuttuu mahdollisuus tai kyky muodostaa merkityksiä, ajatella ja työstää tutkimusta omalla äidinkielellään. Olemme varmaan kaikki törmänneet sellaisiin teksteihin. Ihmistieteissä yksikielisyys millä kielellä hyvänsä onkin selvästi haitaksi. Jotta tiedeyhteisön keskustelu pysyisi luovana ja tasokkaana, tarvitaan useamman kuin yhden kielen läsnäoloa, jatkuvaa vuorovaikutusta tutkijan äidinkielen, alan kansainvälisen lingua francan ja muiden kielten kanssa.

Yhden kielen ja mielen ideologia oli 1800-luvulla tarpeen suomen kielen emansipoituessa julkiseksi kieleksi. Sen aika on nyt ohi. Yksikielisyys ei ole sen enempää kansallisen kuin kansainvälisenkään kielipolitiikan edellytys. Monikielisyys on sen sijaan suuri henkinen voimavara sekä yksilöille että kieliyhteisöille. Suomen kielen tulevaisuus lähteekin muiden pohjoismaisten ohjelmien tapaan ns. rinnakkaiskielisyyden periaatteesta. Kansainvälisillä areenoilla on yleensä tarkoituksenmukaista käyttää englantia tai muuta vierasta kieltä, kotimaisissa yhteyksissä taas suomea tai muuta kotimaista kieltä.

Nuo ovat siis tavanomaisimpia vaihtoehtoja, mutta kielten rinnakkaiskäyttöä voi tutkijoiden kohtaamisissa varioida monella muullakin tavalla. Viime aikoina monikielisyyden mahdollisuuksia vuorovaikutuksessa on kokeiltu alustavasti omassa kotilaitoksessani - siinä kaksikielisessä suomen, suomalais-ugrilaisten ja pohjoismaisten kielten ja kirjallisuuksien suurlaitoksessa, joka vuodenvaihteessa syntyy virallisesti Helsingin yliopistoon. Keskustelussa jokainen voi puhua sitä kieltä, mitä haluaa. Useimmiten se on oma äidinkieli tai jokin muu tuttu kieli, jota parhaiten osaa ja keskustelukumppanit ymmärtävät. On hämmästyttävää, miten tarkaksi ja syvälliseksi tutkijoiden ja opiskelijoiden tieteellinen keskustelu voi näillä ehdoin muuttua. 


\section{Viitteet}

${ }^{1}$ Suomen kielen tulevaisuus: kielipoliittinen toimintaohjelma. Kirjoittajat: Auli Hakulinen, Jyrki Kalliokoski, Salli Kankaanpää, Antti Kanner, Kimmo Koskenniemi, Lea Laitinen, Sari Maamies, Pirkko Nuolijärvi. Helsinki 2009. Kotimaisten kielten tutkimuskeskus, Verkkojulkaisuja 7. Ks. http://scripta.kotus.fi/www/verkkojulkaisut/julk7/

${ }^{2}$ http://www.analysnorden.org/pub/2002aarsberet/F/14.htm

${ }^{3}$ Pohjoismainen kielipoliittinen julistus. Suomeksi ks. http://www.kotus.fi/?s=239

${ }^{4}$ Suomessa aihetta käsiteltiin vuonna1998 alustavasti Kotuksen kielipoliittisessa periaateohjelmassa (http://www.kotus.fi/index. phtml?s=2064).

${ }^{5}$ Niiden alustaviin versioihin voi tutustua osoitteessa http://www.kotus.fi/index.phtml?s=2162.

Jo vuonna 2003 Kotus julkaisi myös laajan suomenruotsin strategian Tänk om

(http://scripta.kotus.fi/www/verkkojulkaisut/tank_om/).

${ }^{6}$ Palautetta voi lähettää osoitteeseen skt-palaute@kotus.fi 